18.), mentions that the continued state of emergency throughout the year has again been responsible for fewer visitors; but in view of the fact that few Africans could enter Nairobi, the reduction was not so much as was anticipated. Much curatorial work was accomplished, especially the development of a new Hall of Mammals, and work on transforming a large room into a Bird Gallery was in progress. Many important field trips were made for collecting, especially to a part of East Africa otherwise difficult of access and of great botanical interest. A wellpreserved hand of a Mioceno ape was found in blocks of limestone at Rusinga, and a nearly complete skull of a lemuroid was another important discovery. All this material is now being closely examined by a group of specialists.

\section{The Night Sky in October}

FULL moon oceurs on Oet. 1d. 19h. 17m., U.T., and new moon on Oct. 15d. $19 \mathrm{~h}, 32 \mathrm{~m}$. The following conjunctions with the Moon take place: Oct. 11d. 16h., Jupiter $6^{\circ}$ N. ; Oct. 14d. 09h., Mars $6^{\circ}$ N. ; Oct. 17d. 00h., Venus $4^{\circ}$ N. ; Oct. 18d. 05h., Saturn $4^{\circ} \mathrm{N}$. In addition to these conjunctions with the Moon, Mercury is in conjunction with Venus on Oct. 8 d. $08 \mathrm{~h}$., Mercury $4.3^{\circ} \mathrm{S}$., and Venus is in conjunction with Saturn on Oct. $30 \mathrm{~d} .22 \mathrm{~h}$., Venus $2^{\circ} \mathrm{S}$. Mercury is too close to the Sun during the greater part of October for observation, but towards the end of the month it rises about an hour and a half before sunrise and is visible for a short time in the eastern sky. Venus sets shortly after the Sun during the month and is not favourably placed for observation. Mars rises about $4 \mathrm{~h} .30 \mathrm{~m}$. throughout October and is visible in the constellation Leo in the early part of the month, moving later into Virgo, and is close to $\eta$ Virginis about October 19 and to $\gamma$ Virginis about October 28 , its stellar magnitude remaining $2 \cdot 0$ during this time. Jupiter rises at $1 \mathrm{~h} .50 \mathrm{~m}, 1 \mathrm{~h}, 10 \mathrm{~m}$. and $0 \mathrm{~h} .20 \mathrm{~m}$. on October 1,15 and 31 , respectively. Its eastward movement in Leo is easily seen, and towards the end of the month it is very close to $\alpha$ Leonis. Its stellar magnitude varies from $-1 \cdot 4$ to -1.5 owing to its distance from the Earth decreasing from 558 to 522 million miles during the month. Saturn sets at $19 \mathrm{~h} .10 \mathrm{~m} ., 18 \mathrm{~h} .15 \mathrm{~m}$. and $17 \mathrm{~h} .20 \mathrm{~m}$. on October 1, 15 and 31, respectively. Its eastward movement can be detected by noticing that it approaches $\gamma$ Librae during the month. Its stellar magnitude remains $0 \cdot 8$, although its distance from the Earth increases from 991 to 1,013 million miles during October. The Orionid meteor shower attains a maximum during October $20-23$; the radiant at R.A. $6 \mathrm{~h} .24 \mathrm{~m}$., Dec. $15^{\circ} \mathrm{N}$., near the north-east of the constellation Orion, is close to $\gamma$ Geminorum.

\section{Announcements}

THE ninth Eddington Memorial Lecture will be given by Prof. R. B. Braithwaite, of King's College, Cambridge, on November 22, at 5.15 p.m., in Oxford. He will speak on "An Empiricist's View of the Nature of Religious Belief".

Dr. W. B. Litriege has been promoted to a chief scientific officer and appointed principal director of scientific rescarch (defence), Ministry of Supply, in succession to Dr. W. Cawood, who is to become principal director of scientific research (air) on November 1 .

Dr. W. Steven has been appointed superintendent of the Development and Research Department
Laboratory of the Mond Nickel Cornpany, Ltd., Birmingham, in succession to the late Mr. Howard Evans. Dr. Steven, who is a graduate of the University of Glasgow, was for five years engaged in research and works control on tool steels, constructional steels and stainless steels at Wm. Jessop and Sons, Ltd., Sheffield. Then in July 1947 he joined the Mond Nickel Company, where he has been working on alloy steels and cast irons, particularly on transformation in steels and problems associated with spheroidalgraphite cast iron. He was at one time secretary of the Hardenability Sub-Committee of the Ministry of Supply Special and Alloy Steels Committee.

Mr. F. S. O. BrovgHTon, assistant secretary of the Development Commission, has been appointed to succeed Mr. E. H. E. Havelock as secretary of the Commission. Mr. Havelock will continue to serve the Commission for a further period as secretary to a committee appointed to inquire into and advise upon the future organization of fishery research.

THE Science Museum, London, is showing for about six months a special exhibition on the evolution of the dividing machine. Until the middle of the eighteenth century, measuring scales of scientific and other instruments were divided by hand or by the use of a dividing plate, but in $\mathbf{1 7 7 5}$ Jesse Ramsden built a successful dividing engine which divided circular scales mechanically. Since his time progress has been in the direction of automatic operation of the machines and increased accuracy of their work. The eight circular dividing machines to be shown range in date from 1778 to 1955 , and two of them will be shown in operation.

DR. GABRIEL KRON will deliver three lectures at the Imperial College of Science and Technology, London, on the "Method of Tearing" on October 7 and 8. He will discuss a technique for the numerical and analytical solution of complex physical systems such as large electrical networks and large mechanical structures. Further particulars can be obtained from the Deputy Registrar, City and Guilds College, Imperial College, London, S.W.7.

THE annual reports for 1954 of the British Rubber Development Board and of Rubber Technical Developments, Ltd. (pp. 47 and 15, respectively; from the Board at Market Buildings, Mark Lane, London, E.C.3), refer to progress in the development of unwoven fabrics bonded with rubber deposited from latex, the use of rubber in roadmaking, rubber rail pads (inserted between rail and sleeper), and the use of latex foam in furniture.

The Electron Microscopy Group of the Institute of Physics is arranging a conference on "The Electron Microscopy of Textile and Other Industrial Fibres", to be held in the University of Leeds during January 3-4. The main groups of topics it is hoped to discuss are specimen techniques, the fine structure of cellulose, synthetic and protein fibres and the surface properties of fibres. Correspondence relating to the conference should be addressed to Dr. J. Sikorski, Textile Physics Laboratory, University, Leeds 2, and sent to him as soon as possible.

TN Nature of September 17, p. 526, there was a review of "Michael 'T'swett's First Paper on Chromatography", issued by M. Woelm, of Eschwege. L. Light and Co., Ltd., Poyle Estate, Colnbrook, Bucks, are the British agents for M. Woelm for the sale of their activated alumina for chromatography, and they have a few copies of the brochure; it is free of charge. 